Analisis Gender atas Ayat-Ayat Reproduksi Perempuan | 25

\title{
ANALISIS GENDER ATAS AYAT-AYAT REPRODUKSI PEREMPUAN DALAM ALQUR'AN
}

\author{
Nafisatul Mu'awwanah \\ Fakultas Ushuluddin dan Pemikiran Islam, UIN Sunan Kalijaga Yogyakarta \\ Nafisatulmuawwanah24395@gmail.com
}

\begin{abstract}
:
In addition to experiencing a heavy reproductive burden, women often receive discriminatory treatment from society because of the reproductive cycle they experience. Discriminatory behavior like this was reflected in preIslamic Arab society, wherein the Alquran came down to carry out a cultural transformation of the patriarchal system at that time. This paper is a critical study of the verses of the Alqur'an about women's reproduction from a gender perspective. In the study of gender, at least this paper tries to reveal two things: first, how to understand the reproductive verses of women in the Alqur'an; second, what is the form of cultural transformation of the Alquran towards gender discrimination related to the women's reproductive system. From the results of the study it can be concluded that; first, the Alquran has discussed various women's issues, including issues related to their reproductive system. There are at least five women reproductive cycles discussed in the Alqur'an, namely regarding menstruation, conception or sex, pregnancy, childbirth, and breastfeeding. Second, when referring to pre-Islamic Arabic culture, the Alqur'an has actually carried out a cultural transformation of a patriarchal system that is very discriminatory against women. The Qur'an emphasizes that men and the environment are involved regarding the responsibilities and risks of the reproductive system experienced by women.
\end{abstract}

Keywords: The verses of the Alqur'an on Women's Reproduction, Gender Justice, the Reproductive Cycle of Women.

\begin{abstract}
Abstrak:
Di samping mengalami beban reproduksi yang berat, perempuan kerap mendapatkan perlakuan yang diskriminatif dari masyarakat karena siklus reproduksi yang dialaminya. Prilaku diskriminatif seperti ini tercermin dalam masyarakat Arab pra-Islam, yang selanjutnya Alqur'an turun untuk melakukan transformasi kultural terhadap sistem patriarki ketika itu. Tulisan ini merupakan kajian kritis atas ayat-ayat Alqur'an tentang reproduksi perempuan dalam perspektif gender. Dalam kajian gender, paling tidak tulisan ini berusaha mengungkap tentang dua hal: pertama, bagaimana pemahaman ayat-ayat reproduksi perempuan dalam Alqur'an; kedua, bagaimana bentuk transformasi kultural Alqur'an terhadap diskriminasi gender yang berkaitan dengan sistem reproduksi perempuan. Dari hasil kajian dapat disimpulkan bahwa; pertama, Alqur'an telah membicarakan berbagai persoalan perempuan, termasuk di dalamnya persoalan-persoalan yang berkaitan dengan sistem reproduksi mereka. Setidaknya terdapat lima siklus reproduksi perempuan yang dibicarakan oleh Alqur'an, yaitu berkenaan dengan menstruasi, pembuahan atau seks, kehamilan, melahirkan, dan menyusui. Kedua, ketika merujuk kepada kebudayaan Arab pra-Islam maka sesungguhnya Alqur'an telah melakukan transformasi kultural terhadap sistem patriarki yang sangat diskriminatif terhadap perempuan. Alqur'an menegaskan agar laki-laki dan lingkungan turut terlibat terkait tanggung jawab dan resiko sistem reproduksi yang dialami perempuan.
\end{abstract}

Kata Kunci: Ayat-ayat Reproduksi Perempuan, Keadilan Gender, Siklus Reproduksi Perempuan.

\section{PENDAHULUAN}

Secara biologis, perempuan dan laki-laki memiliki fungsi reproduksi ${ }^{1}$ yang berbeda. Organ reproduksi perempuan lebih banyak dan fungsinya lebih kompleks dari pada

1 Secara sederhana reproduksi berasal dari kata re yang berarti kembali dan produksi yang berarti membuat atau menghasilkan. Jadi reproduksi mempunyai arti suatu proses kehidupan manusia dalam 


\section{6 | Analisis Gender atas Ayat-Ayat Reproduksi Perempuan}

organ reproduksi laki-laki. Perempuan mengalami menstruasi, proses pembuahan atau seks, hamil, melahirkan, dan menyusui, sedangkan laki-laki hanya membuahi dengan spermatozoa. Fungsi reproduksi perempuan lebih banyak dari pada laki-laki disebabkan karena secara alamiah perempuan memiliki organ reproduksi tersebut, seperti memiliki vagina, mempunyai rahim dan memiliki kelenjar susu atau mamae. ${ }^{2}$

Namun, pandangan masyarakat yang lahir dari perbedaan sistem dan fungsi reproduksi ini seringnya melahirkan diskriminasi, yang di antaranya adalah beban kerja yang tidak proporsional terhadap perempuan. Misal dalam sistem patriarki, pekerjaan domestik yang dibebankan kepada perempuan menjadi identik dengan diri perempuan. Dalam ranah domestik perempuan harus memasak, mencuci, menyetrika, membimbing belajar anak, dan lain sebagainya. Pekerjaan domestik yang berat tersebut dilakukan bersama-sama dengan fungsi reproduksi, seperti haid, hamil, melahirkan, dan menyusui. Sementara laki-laki dengan peran publiknya menurut kebiasaan masyarakat tidak bersentuhan dengan beban kerja domestik-reproduktif, karena pekerjaan ini dipandang hanya layak dikerjakan oleh perempuan. ${ }^{3}$

Perlakukan diskriminatif karena perbedaan sistem dan fungsi reproduksi juga sangat terlihat dalam tradisi masyarakat Arab pra-Islam. Kebudayaan diskriminatif terhadap perempuan di masa pra-Islam, terutama dalam permasalahan reproduksi perempuan, di antaranya tercermin dalam perlakukan masyarakat pra-Islam terhadap perempuan menstruasi, perempuan sebagi objek seksual, bahkan sampai pada hinanya seorang ibu yang melahirkan bayi perempuan. Di tengan kebudayaan yang sangat diskriminatif terhadap perempuan ini, Alqur'an turun untuk melakukan transformasi kultural terhadap sistem patriarki ketika itu. Dalam hal ini, ditemukan ayat-ayat Alqur'an yang secara khusus memperhatikan perempuan dengan sistem reproduksinya, di antaranya adalah menstruasi (QS. al-Baqarah (2): 222), seks atau pembuahan (QS. al-Baqarah (2):223), kehamilan (QS. Luqman (31): 14 dan QS. alAhqaf (46): 15), melahirkan (QS. Maryam (19): 22-26), dan menyusui (QS. al-Thalaq (65): 6 dan QS. al-Baqarah (2): 233).

Paling tidak kajian mengenai sistem reproduksi perempuan dalam Alqur'an sebelumnya telah melahirkan beberapa kecenderungan kajian. Pertama, ayat-ayat kesehatan reproduksi perempuan dalam Alqur'an ditinjau dari segi tematik dan

menghasilkan keturunan demi kelestarian hidup. Namora Lumongga Lubis, Psikologi Kespro "Wanita dan Perkembangan Reproduksinya" Ditinjau dari Aspek Fisik dan Psikologinya (Jakarta: Kencana, 2013), hlm. 1 .

2 Suharnanik dan Ulfah Muhayani “Bias Gender dalam Kamus Bahasa Indonesia on-line (Studi Kritis tentang Pemaknaan Perempuan dalam Kamus Bahasa Indonesia)" dalam Egalita: Jurnal Kesetaraan dan Keadilan Gender, Vol. 10, No. 2, 2015, hlm. 6

3 Khomisah M.A., "Rekontruksi Sadar Gender: Mengurai Masalah Beban Ganda (Duble Bulder) Wanita Karier di Indonesia" dalam Jurnal al-Tsaqafa, Vol. 14, N0. 2, 2017, hlm. 339 
konseptual (Nur Rofi'ah dan Ina Salma Febriany, 2019'; Ratna Dewi, 20195). Kedua, reproduksi perempuan dalam perspektif hukum Islam (La Ode Angga, 20116; Naan, 20197). Ketiga, reproduksi dan seksualitas perempuan dalam Alqur'an, serta kaitannya dengan wacana patriarki (Neng Hannah, 2017'). Kajian dalam tulisan ini diharapkan dapat melengkapi kekurangan dari kajian-kajian sebelumnya, yaitu berupa kajian kritis atas ayat-ayat Alqur'an tentang reproduksi perempuan dalam perspektif gender. Dalam kajian gender, paling tidak tulisan ini berusaha mengungkap tentang dua hal: pertama, bagaimana pemahaman ayat-ayat reproduksi perempuan dalam Alqur'an; kedua, bagaimana bentuk transformasi kultural Alqur'an terhadap ketidakadilan atau diskriminasi gender yang berkaitan dengan sistem reproduksi perempuan.

\section{PEMBAHASAN}

\section{Gender sebagai Teori: Alat untuk Memahami Ketidakadilan Gender}

Pandangan Alqur'an terhadap sistem dan fungsi reproduksi perempuan dalam tulisan ini dianalisis melalui teori gender. Dan teori gender yang digunakan dalam tulisan ini adalah analisis gender yang dikemukakan oleh Mansour Fakih. Menurut Mansour Fakih, sebelum memahami gender sebagai teori, perlu memahami gender sebagai konsep. Pemahaman atas gender sebagai konsep sangat diperlukan mengingat dari konsep ini telah lahir suatu analisis atau teori gender. ${ }^{9}$

Secara konseptual, sebagaimana dikutip dari bukunya Inayah Rohmaniyah, bahwa gender merupakan sebuah konstruksi sosial tentang pembedaan antara lakilaki dan perempuan, dan bukan suatu yang bersifat biologis. Pembedaan gender ini dibangun secara sosial-kultural, baik perbedaan status, sifat, peran, maupun tanggung jawab antara laki-laki dan perempuan. Hal ini memiliki maksud bahwa pembedaan ini dibangun, disosialisasikan, dan dilanggengkan oleh masyarakat dan diletakkan sebagai identitas tertentu bagi laki-laki atau perempuan. Pembedaan ini juga menyangkup pembagian kerja yang dianggap tepat bagi laki-laki dan perempuan, serta apa yang harus dan tidak harus dilakukan oleh laki-laki dan perempuan. ${ }^{10}$

$4 \quad$ Nur Rofi'ah dan Ina Salma Febriany, “Islam dan Upaya Peningkatan Kesehatan Reproduksi Perempuan: Tinjauan Kritis Ayat-ayat Reproduksi" dalam al-Tadabbur: Jurnal Kajian Sosial, Peradaban dan Agama, vol. 5, no. 2, 2019.

5 Ratna Dewi, “Konsep Kesehatan Reproduksi Perempuan dalam al-Qur'an” dalam Mawa'izh: Jurnal Dakwah dan Pengembangan Sosial Kemanusiaan, vol. 10, no. 2, 2019.

6 La Ode Angga "Hak Reproduksi Perempuan dalam Perspektif Syari' ah Islam" dalam Muwazah, vol. 3, no. 2, 2011.

7 Naan, Hak dan Kesehatan Reproduksi Perempuan dalam Islamdalam http://digilib.uinsgd.ac.id diakses pada tanggal 15 April 2021.

8 Neng Hannah, "Seksualitas dalam Alqur'an, Hadis, dan Fiqih: Mengimbangi Wacana Patriarki" dalam Wawasan: Jurnal Ilmiah Agama Sosial Budaya, vol. 2, no. 1, 2017.

9 Mansour Fakih, Analisis Gender dan Transformasi Sosial (Yogyakarta: Pustaka Pelajar, 2012), hlm. 4

10 Inayah Rohmaniyah, Gender dan Konstruksi Patriarki dalam Tafsir Agama (Yogyakarta: Suka Press, 2020), hlm. 15. 
Oleh karena itu, pembedaan gender merupakan sebuah konstruksi sosial yang tidak bersifat kodrati. Inilah yang membedakan antara gender dan jenis kelamin. Jenis kelamin sendiri merupakan pensifatan secara biologis dan bersifat kodrati. Secara jenis kelamin, laki-laki adalah manusia yang memiliki penis dan memproduksi sperma, sedangkan perempuan adalah jenis manusia yang memiliki vagina dan alat reproduksi lainnya. Alat-alat ini secara permanen melekat pada masing-masing jenis kelamin dan tidak dapat dipertukarkan. Berbeda dengan jenis kelamin, gender merupakan persifatan bagi laki-laki dan perempuan yang dibangun secara sosial atau kultural. ${ }^{11}$

Selanjutnya, pembedaan gender atau pembedaan laki-laki dan perempuan yang dibentuk oleh masyarakat telah melahirkan ketidakadilan gender. Pembedaan gender sesungguhnya tidak masalah sepanjang tidak melahirkan ketidakadilan gender. Namun, yang menjadi persoalan adalah perbedaan gender telah melahirkan berbagai ketidakadilan atau diskriminasi, baik terhadap kaum laki-laki maupun kaum perempuan. Ketidakadilan gender merupakan sistem dan struktur di mana baik kaum laki-laki maupun kaum perempuan menjadi korban dari sistem tersebut. ${ }^{12}$

Pembedaan gender yang melahirkan ketidakadilan inilah yang menurut Mansour Fakih dikritisi oleh analisis gender. ${ }^{13}$ Oleh karena itu, teori gender digunakan untuk mengidentifikasi pada bentuk ketidakadilan struktur dan sistem yang disebabkan oleh gender. Secara umum menurut Mansour Fakih, bentuk ketidakadilan yang disebabkan oleh pembedaan gender adalah subordinasi (penomorduaan) atau anggapan tidak penting dalam sebuah keputusan, marginalisasi atau peminggiran yang merugikan salah satu pihak, stereotipe atau pelabelan negatif, beban kerja berlebih atau burden, dan kekerasan gender atau violence. ${ }^{14}$

Sebagaimana yang telah disebutkan, gender sebagai alat analisis umumnya dipergunakan untuk memusatkan pada ketidakadilan struktur dan sistem yang disebabkan oleh pembedaan gender. Mulanya, analisis gender merupakan analisis kritis yang mempertajam analisis kritis yang sudah ada, yang mempertanyakan ketidakadilan sosial dari aspek hubungan antar jenis kelamin. Analisis kritis yang sudah ada misalnya adalah analisis kelas yang dikembangkan oleh Karl Marx ketika melakukan kritik kepada sistem kapitalis, analisis hegemoni ideology dan cultural yang dikemukakan oleh Antonio Gramsci, dan Analisis Kritis penganut adzhab Frankfrut yang memusatkan perhatian pada perkembangan kapitalisme dan epistemologi positivisme. Semua analisis tersebut berupaya dalam memerangi ketidakadilan sosial yang selanjutnya melahirkan analisis dan teori sosial sebagaimana yang telah disebut. Dari berbagai gugatan terhadap ketidakadilan, analisis gender mencoba mempertanyakan ketidakadilan sosial dari aspek hubungan antar jenis kelamin. ${ }^{15}$

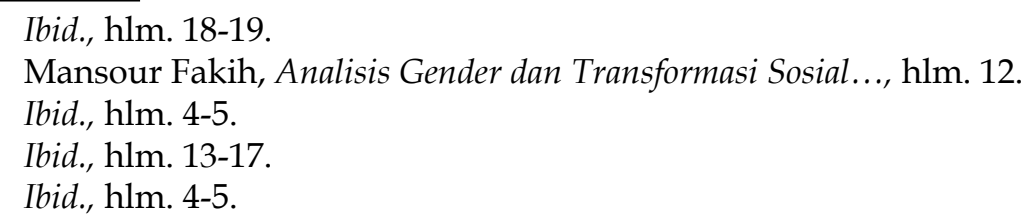




\section{Ayat-ayat Reproduksi Perempuan dalam Alqur'an}

Dalam Alqur'an paling tidak ditemukan lima pengalaman biologis perempuan terkait dengan sistem reproduksi. Sistem reproduksi tersebut meliputi menstruasi (haidl), pembuahan atau seks, kehamilan, melahirkan, dan menyesui. Oleh karena itu, dalam bagian ini akan dijelaskan tentang ayat-ayat dalam Alqur'an yang berkaitan dengan sistem reproduksi perempuan.

\section{Menstruasi}

Menstruasi secara biologis merupakan siklus reproduksi yang menandai berfungsinya organ-organ reproduksi perempuan. Perempuan yang sudah mengalami siklus menstruasi terdapat indikasi bahwa perempuan tersebut telah mampu bereproduksi. Selain itu, juga menunjukkan akan kematangan seksualitas perempuan, yang dalam artian bahwa ia mempunyai ovum yang siap dibuahi, bisa hamil, dan melahirkan. ${ }^{16}$

Secara khusus ayat Alqur'an yang berbicara tentang permasalahan menstruasi adalah QS. al-Baqarah (2): 222, yang dalam ayat ini menggunakan terma haidl. ${ }^{17}$ QS. al-Baqarah (2): 222 dimulai dengan pertanyaan para sahabat kepada nabi Muhammad tentang apa itu haidl. Pertanyaan ini dikemukakan ketika para sahabat melihat orangorang Yahudi yang menjahui istrinya yang sedang menstruasi dengan tidak memberi makan dan tidak menggauli mereka di rumah. Kemudian dijawablah oleh Allah melalui turunnya ayat ini, bahwa hadl adalah $a d z a .^{18}$

Seringnya kata adza dalam ayat ini diterjemahkan sebagai kotoran. Kotoran menunjukkan sebuah konotasi yang negatif, yaitu sesuatu yang menjijikkan dan harus dijauhi. Sedangkan haidl adalah pemberian Tuhan yang merupakan kodrat bagi perempuan. ${ }^{19}$ Nampaknya, terma yang tepat untuk menyebut kotoran bukanlah adza namun rijsun, yang diartikan sebagai kotor berdasarkan pandangan agama, akal, dan tabiat manusia, dan seringnya disandarkan kepada khamr, judi, atau bangkai. ${ }^{20}$ Sehingga, kurang begitu tepat jika adza diterjemahkan sebagai kotoran.

16 Secara biologis wanita dilengkapi substansi sumber kehidupan yang disebut ovarium (indung telur). Dalam keadaan subur, ovum yang terbuai membentuk kehidupan baru. Ovum yang kadaluarsa akan gugur menjadi darah manusia. Siklus ini akan terjadi berulang-ulang sebagai urutan menstruasi.

17 Katahaild dan derivasinya dalam Alqur'an disebut sebanyak empat kali, yaitu sekali dalam bentuk fi'il mudlari' (QS. al-Thalaq (65): 4) dan tiga kali dalam bentuk isim masdar (sekali dalam QS. alBaqarah (2): 222 dan dua kali dalam QS. al-Thalaq (65): 4). Secara bahasa haidl memiliki arti mengalir. Oleh karena itu itu lembah bisa disebut dengan haudl karena sama halnya mengalirnya air di suatu lembah ketika datang hujan. Abu al-Qasim al-Husein bin Muhammad ar-Raghib al-Asfahani, al-Mufradat fi Gharib al-Qur'an, ed. Muhammad Khalil ‘Itaniy (Beirut: Dar al Ma'rifah, 2005) hlm. 179.Kemudian haidl dikhususkan kepada darah yang mengalir dari rahim perempuan dalam waktu tertentu. Darah haidl mengalir dari rahim perempuan ketika perempuan dalam kondisi sehat, yang merupakan kodrat bagi perempuan. Muhammad Sayyid Thanthawi, at-Tafsir al-Wasith lil Qur'an al-Karim (Mesir: al-Hai'ah al'Amah li Syu' un al-Mathabi' al-Amiriyyah, 2013), hlm. 262.

18 Imam Abu Hasan Ali bin Ahmad al-Wahidi, Asbab Nuzul al-Qur'an (Beirut: Dar al-Kutub al'Alamiyah, 1991), hlm. 76.

19 Zaitunah Subhan, Al-Qur'an dan Perempuan: Menuju Kesetaraan Gender dalam Penafsiran (Jakarta: Kencana, 2015), hlm. 234.

20 Nur Rofi'ah dan Ina Salma Febriany, "Islam dan Upaya Peningkatan Kesehatan Reproduksi Perempuan..., hlm. 203. 
Dalam Alqur'an sendiri kata adza disebut sebanyak delapan kali, yaitu QS. alBaqarah (2): 196, 222, 262, 263, dan 264, QS. Ali Imran (3): 111 dan 186, dan QS. anNisa' (4): 102. ${ }^{21}$ Menurut Quraish Shihab, kata adza dalam ayat-ayat tersebut bermakna halangan atau gangguan, bukan kotoran..$^{22}$ Begitupun dengan Tanthawi dalam TafsiralWasith mengatakan bahwa adza adalah sesuatu yang melukai manusia dan apabila manusia mengalaminya maka dapat menyebabkan adanya dlarurat, atau gangguan. ${ }^{23}$

Lebih lanjut, menurut Quraish Shihab, haidl dalam QS. al-Baqarah (2): dikatakan sebagai gangguan karena dapat mengakibatkan gangguan terhadap fisik dan psikis wanita. Secara fisik, keluarnya darah karena haidl dapat mengakibatkan rasa sakit yang seringkali melilit perempuan. Sedangkan secara psikis, haid mengakibatkan nafsu seksual wanita menjadi menurun, karena emosi yang seringkali tidak terkontrol. Selain itu, haidl juga dapat menyebabkan gangguan terhadap laki-laki. Darah yang aromanya tidak sedap serta tidak menyenangkan untuk dilihat merupakan salah satu aspek gangguan pada pria, disamping emosi istri yang tidak stabil. ${ }^{24}$

Oleh sebab itu, perintah Alqur'an adalah fa'tazilu an-nisa' fi al-mahidl, janganlah bersetubuh dengannya pada tempat keluar haidl tersebut. Disamping karena menyebabkan ketidaknyamanan pada suami-istri, juga kerana secara biologis, datangnya haidl menandakan bahwa sel telur pecah, sehingga pembuahan tidak mungkin terjadi pada masa menstruasi. Namun, melalui hadisnya Nabi mengizinkan untuk bercumbu pada bagian atas, tidak di bagian keluarnya haidl. ${ }^{25}$ Dalam tafsir alWasith dijelaskan bahwa kata i'tazalu (jauhilah) dalam ayat ini adalah sebuah kiasan, yang maksudnya adalah meninggalkan jima' atau berhubungan badan. Sedangkan lawannya, yaitu iqrabu (dekatilah) memiliki arti melakukan jima' atau berhubungan badan. Jadi, konteks yang ada dalam ayat ini adalah hanya larangan dalam hal jima' bukan larangan menjahui dalam interaksi sosial. ${ }^{26}$

\section{Seks atau Pembuahan}

Fungsi reproduksi yang dialami perempuan selanjutnya adalah berhubungan seks yang dengan ini terjadi proses pembuahan. Alqur'an memberikan kepada perempuan hak-hak yang sama dengan laki-laki, terutama dalam kenikmatan hubungan seksual, wa lahunna mistl al-ladzi 'alaihunna bi al-ma'ruf (QS. al-Baqarah (2): 228). Dalam relasi seksual, Islam juga memberikan perempuan hak penikmatan seksual sebagaimana yang dinikmati laki-laki. Satu teks Alqur'an menggambarkan relasi seksual laki-laki perempuan dengan kalimat yang indah, hunna libasun lakum wa antum libasun lahunna,

21 Zaitunah Subhan, Al-Qur'an dan Perempuan..., hlm. 235-236

22 Quraish Shihab, Tafsir al-Misbah: Pesan, Kesan, dan Keserasian al-Qur'an (Jakarta: Lintera Hati, 2006), Jilid 1, hlm. 478-479.

${ }_{23}$ Muhammad Sayyid Thanthawi, at-Tafsir al-Wasith..., hlm. 263.

24 M. Quraish Shihab, Tafsir al-Misbah..., Jilid 1, hlm. 478-479.

25 Ibid.

26 Muhammad Sayyid Thanthawi, at-Tafsir al-Wasith..., hlm. 364. 
mereka (istri-istrimu) adalah pakaian bagi kalian dan kalian adalah pakaian bagi mereka (istri-istrimu). ${ }^{27}$

Terlepas dari kedua ayat di atas, perempuan sering dianggap sebagai obyek seksualitas karena diibaratkan dengan harst (ladang), yang tercantum dalam QS. alBaqarah (2): 223. Dalam ayat tersebut dikatakan bahwa nisa'ukum harstun lakum fa'tu harsakum anna syi'tum, "istri-istrimu adalah harst bagimu, maka datangilah harst-mu itu bagaimana kamu kehendaki (menyetubuhi)". Berdasarkan ayat tersebut, perempuan ibarat harst bagi suaminya. Dan harst dalam ayat ini sering diartikan sebagai "tanah tempat bercocok tanam".

Harst dalam ayat ini berkaitan dengan pembuahan melalui hubungan seks. Kata harst sendiri dalam Alqur'an disebut sebanyak 13 kali. Beberapa di antaranya adalah tahrutsun (QS. al-Waqi'ah (56): 63), hartsun (QS. al-Baqarah (2): 71, 205, 223, QS. Ali Imran (3): 14, 117, QS. al-An'am (6): 136, 138, QS. al-Anbiya' (21): 78, QS. asy-Syura (42): 20, dan QS. al-Qalam (68): 22). Makna dasar dari harst adalah mempersiapkan lahan dengan cara membajak agar dapat meletakkan benih di dalamnya. Kemudian kata harst ini dimutlakan kepada makna 'tanah yang dapat ditanami' (al-ardl al-mazru'ah). ${ }^{28}$

Menurut Quraish Shihab, istri yang diibaratkan dengan ladang atau tempat bercocok tanam bukanlah tanpa alasan. Ibarat ladang, sebuah ladang tidak boleh disalahkan jika dalam ladang tersebut tumbuh apel sementara yang diharapkan petani adalah buah mangga. Bagitupun dalam konteks hubungan suami-istri, maka istri tidak bisa disalahkan jika dalam proses pembuahan yang lahir adalah anak perempuan sedangkan yang diharapkan adalah anak laki-laki, karena di sini terdapat dua kromoson, yaitu yang terdapat pada perempuan $(X X)$ dan yang terdapat pada laki-laki (XY) sebagai faktor pembentuk kelamin. ${ }^{29}$

Lebih lanjut, Qurash Shihab menegaskan bahwa pembuahan melalui seks terjadi tidak hanya tanggung jawab istri, namun juga suami. Ibarat ladang, pasti tidak ada seorang petani yang menginginkan panennya gagal. Petani harus pandai dalam memelihara dan menjaga ladangnya tetap subur. Ibarat ladang yang harus diatur masa tanamnya, seorang suami juga harus turut mengatur masa reproduksi istri. Suami harus memilih waktu yang tepat, dan mengatur masa kehamilan, karena panen setiap saat juga dapat merusak ladang. Selain itu, panen akan berhasil jika di ladang tidak diserang hama dan dipupuk sesuai dengan kebutuhan. ${ }^{30}$ Dalam konteks suami-istri, hendaknya suami lebih memperhatikan istrinya. Suami harus menghindarkan istri dari berbagai gangguan, yang ibarat ladang adalah hama. Suami harus memberikan berbagai kebaikan untuk menyiapkan pertumbuhan dan perkembangan janin yang akan dikandungnya. Meski suami diberi kebebasan dalam berhubungan intim atau

27 Husein Muhammad, Islam Agama Ramah Perempuan: Pembelaan Kiai Pesantren (Yogyakarta: LKiS, 2004), hlm. 261.

${ }_{28}$ Abu al-Qasim al-Husein bin Muhammad ar-Raghib al-Asfahani, al-Mufradat fi Gharib al-Qur'an, ed. Muhammad Khalil 'Itaniy (Beirut: Dar al Ma'rifah, 2005) hlm. 147.

29 M. Quraish Shihab, Tafsir al-Misbah..., jilid. 1, hlm. 480.

$30 \quad$ Ibid., hlm. 481. 


\section{2 | Analisis Gender atas Ayat-Ayat Reproduksi Perempuan}

mendatangi istrinya, namun harus dilandasi pada tujuan untuk kemaslahatan di dunia dan di akhirat.

\section{Kehamilan}

Siklus reproduksi perempuan selanjutnya adalah kehamilan atau mengandung. Dalam beberapa ayatnya, Alqur'an sangat empatik kepada perempuan mengandung. Alqur'an menekankan perlunya suami dan masyarakat memperhatikan dengan sungguh-sungguh soal kehamilan perempuan. Hal ini disebabkan karena kehamilan merupakan siklus reproduksi yang sangat berat dan melemahkan.

Di antara ayat Alqur'an yang menyinggung proses kehamilan adalah QS. Luqman (31): 14 dan QS. al-Ahqaf (46): 15. Alqur'an melalui dua ayat tersebut berwasiat agar manusia berbuat baik kepada orang tua mereka, khususnya ibu. Dalam QS. Luqman (31): 14 digambarkan bahwa perempuan mengandung berada dalam kondisi wahnan 'ala wahnin. Al-wahnu secara bahasa adalah al-dla'fu, yang berarti lemah. ${ }^{31}$ Dalam tafsir al-Wasith dijelaskan bahwa maksud dari wahnan 'ala wahnin adalah lemah di atas lemah yang terus bertambah di setiap waktu, disebabkan bertambahnya ukuran janin. Kata ini menggambarkan akan bentuk kelelahan selama kehamilan dan persalinan. ${ }^{32}$

Sedangkan menurut as-Sa' di kata al-wahnu dalam ayat ini adalah al-masyaqqah, yang berarti kesulitan. Sehingga ungkapan wahnan 'ala wahnin dapat diartikan sebagai kesulitan atas kesulitan, yang berupa rasa sakit yang terus menerus, lemah, berat, yang dimulai setelah saat pembuahan dan puncak sakitnya adalah masa melahirkan. ${ }^{33}$ Hal ini menunjukkan bahwa beban reproduksi yang diemban perempuan pada masa kehamilan adalah suatu yang berat hingga membuat mayoritas perempuan merasa lelah, tidak berdaya, dan keluhan kehamilan lainnya.

Selain tergambarkan dalam uangkapan wahnan 'ala wahnin, kepayahan yang dirasakan perempuan saat mengandung juga digambarkan oleh Alqur'an melalui ungkapan kurhan dalam QS. al-Ahqaf (46): 15. Kata kurhan berasal dari akar kata kara-ha yang memiliki arti tidak menyukai atau tidak merasa nyaman. Ungkapan ini menunjukkan bahwa kondisi yang dirasakan perempuan saat mengandung kurang disukai atau membuat perempuan tidak merasa nyaman, seperti mual, sakit kepala, cepat merasa lelah, emosi tidak stabil, dan lain sebagainya. Fase ini adalah fase yang sangat berat bagi perempuan dan sukar untuk dilalui. ${ }^{34}$

Alqur'an melalui dua ayat di atas selanjutnya berwasiat kepada manusia agar berbuat baik kepada orang tua mereka, terutama ibu. Kepayahan yang dialami oleh seorang ibu harus melahirkan rasa peduli dalam diri manusia. Keberadaan manusia di

\footnotetext{
31 Abu al-Qasim al-Husein bin Muhammad ar-Raghib al-Asfahani, al-Mufradat fi Gharib alQur'an..., hlm. 694.

32 Muhammad Sayyid Thanthawi, at-Tafsir al-Wasith..., jilid 8, hlm. 88.

33 Tafsir as-Sa'di atas QS. Luqman (31): 14 dalam Program Ayat-ayat Situs al-Qur'an, King Saud University.

34 Nur Rofi'ah dan Ina Salma Febriany, "Islam dan Upaya Peningkatan Kesehatan Reproduksi Perempuan..., hlm. 214.
} 
dunia ini adalah bentuk pengorbanan orang taunya, terutama ibunya dalam melewati rasa sakit selama berbulan-bulan lamanya.

\section{Melahirkan}

Setelah mengalami fase kehamilan, siklus reproduksi perempuan selanjutnya adalah persalinan atau melahirkan. Persalinan adalah proses pergerakan keluarnya janin, plasenta, dan membran dari dalam rahim melalui jalan lahir. Proses ini berawal dari pembekuan dan dilatasi serviks akibat kontraksi uterus dengan frekuensi, durasi, dan kekuatan yang teratur. ${ }^{35}$ Sedangkan Alqur'an menyebutkan bahwa proses persalinan sendiri merupakan proses alamiah yang luar biasa sekaligus menunjukkan kemahabesaran Allah (QS. an-Nahl (16): 78 dan QS. 'Abasa (80): 20).

Dalam proses persalinan, perempuan tidak lepas dari rasa sakit yang biasa disebut dengan kontraksi. Hal inilah yang juga diterangkan oleh Alqur'an ketika menceritakan proses persalinan yang dialami oleh Maryam (QS. Maryam (19): 22-26). Lafad al-mahadl dalam ayat ini lebih dikenal dengan rasa sakit ketika akan melahirkan, atau biasa disebut dengan kontraksi. ${ }^{36}$ Inilah beban fisik yang dialami oleh perempuan melahirkan. Ketika proses persalinan tiba, sebagaimana perempuan umumnya Maryam mengalami rasa sakit yang luar biasa yang membuatnya merasa kepayahan. Ketika Maryam merasakan sakit karena akan melahirkan Isa, ia terpaksa bersandar pada pangkal pohon kurma untuk memudahkan kelahiran.

Selain mengalami beban fisik, perempuan melahirkan juga mengalami beban psikis. QS. Maryam (19): 22-26 juga menggambarkan bagaimana detik-detik persalinan yang dialami oleh Maryam yang seorang diri tanpa ditemani oleh siapapun. Selain itu, ayat ini juga menginformasikan bahwa beban psikis atas tuduhan kepada Maryam karena hamil tanpa pasangan, menyebabkan dirinya merasa perlu menjauhkan diri untuk memperoleh suasana yang tenang. Bahkan, ia mengharapkan kematian sebelum ia mengalami proses persalinan karena beratnya penderitaan akibat melahirkan seorang anak tanpa ayah yang berakibat timbulnya tuduhan dari masyarakat. ${ }^{37}$ Dalam tafsir al-Wasith dijelaskan bahwa Maryam berangan-angan sekiranya saja dia mati sebelum waktu ini, karena malu dan takut mendapatkan cemoohan, dan menjadi barang yang tidak berarti dan terlupakan. ${ }^{38}$

Ayat tersebut menunjukkan bahwa rasa sakit perempuan melahirkan tidak seharusnya diperberat dengan buruknya kondisi lingkungan sekitar. Perempuan melahirkan harus mendapatkan dukungan dari orang-orang sekitar, terutama suami, agar beban sakit yang dirasakannya bisa berkurang. Dan ketika Maryam mengasingkan

\footnotetext{
35 Iwan Setiawan, "Tafsir Ayat al-Qur'an Tema Keperawatan, Kebidanan, dan Fakta Ilmiahnya” dalam Journal of Health Studies, vol. 1, no. 2, 2017, hlm. 206.

36 M. Quraish Shihab, Tafsir al-Misbah..., Jilid. 8, hlm. 169.

37 Iwan Setiawan, “Tafsir Ayat al-Qur'an Tema Keperawatan..., hlm. 208.

38 Muhammad Sayyid Thanthawi, at-Tafsir al-Wasith..., jilid 6, hlm. 956.
} 


\section{4 | Analisis Gender atas Ayat-Ayat Reproduksi Perempuan}

diri untuk menghindari hinaan masyarakat, menunjukkan bahwa perlunya memberikan ketenangan dan kondisi damai bagi ibu yang hendak melahirkan.

\section{Menyusui}

Selanjutnya, salah satu fungsi reproduksi perempuan, dan merupakan proses biologis yang khusus dialami perempuan adalah menyusui. Dalam Alqur'an sendiri, menyusui biasa menggunakan term radla'ah. Dan di antara ayat yang menjelaskan tentang proses menyusui adalah QS. al-Thalaq (65): 6 dan QS. al-Baqarah (2): 233.

Berdasarkan kedua ayat tersebut, pada hakikatnya menyusui adalah bentuk nafkah yang harus diberikan kepada bayi oleh ayah lewat sang ibu dengan cara persusuan. Ayah berkewajiban memberikan air susu kepada anaknya sesuai dengan kemampuannya, seperti memberikan makanan yang bergizi kepada istrinya yang nantinya memproduksi ASI. Cara yang lainnya adalah dengan mencarikan perempuan lain yang sehat jasmani dan rohaninya untuk menyusukan bayinya jika istrinya berhalangan. Menurut Quraish Shihab seorang suami harus menyadari betapa banyak kebutuhan ibu yang menyusui anaknya, misalnya makanan yang bergizi, serta betapa berat pula tugas itu dilaksanakan oleh ibu. ${ }^{39}$

Berbeda dengan QS. al-Baqarah (2): 233, konteks QS. al-Thalaq (65): 6 lebih kepada istri yang ditalak oleh suaminya. Menurut Thabari, tidak wajib bagi seorang ibu yang ditalak ba'in memberikan ASI kepada anaknya, jika ia memiliki ayah yang mampu. Namun, ibunya lebih berhak memberikan ASI kepada anaknya dibandingkan orang lain. ${ }^{40}$ Kewajiban tersebut dipikulkan kepada ayah anak, kecuali apabila ibunya ingin menyusuinya, maka ibunya lebih berhak melakukakannya dari pada orang lain.

Sedangkan QS. al-Baqarah (2): 233 adalah ayat yang berkaitan dengan kesejahteraan ibu menyusui dan anaknya. Sebagaimana dijelaskan sebelumnya, bahwa ayat ini menegaskan keharusan seorang ayah menafkahi ASI kepada anaknya, dengan cara memenuhi kebutuhan istri yang menyusui anak tersebut. Namun, jika ada suatu hal yang membuat istri tersebut tidak mampu memberikan ASI kepada anaknya, maka boleh disusukan kepada perempuan lain. Dan wajib bagi suami memberikan nafkah kepada seorang penyusu anaknya. Mengenai kadar nafkah itu sendiri, disesuaikan dengan kemampuan ayah anak tersebut. ${ }^{41}$

\section{Konteks Historis Ayat-ayat Reproduksi Perempuan dalam Alqur'an}

Alqur'an seringkali diturunkan dengan latar belakang sosio-historis tertentu, sebagai respon dari permasalahan yang dihadapinya. ${ }^{42}$ Dari sini, Arab dari masa pra-Islam sampai masa awal Islam merupakan hal dasar untuk mengetahui kelahiran dan

39 M. Quraish Shihab, Tafsir al-Misbah..., jilid. 1, 503-504.

40 Abu Ja'far Muhammad bin Jarir ath-Thabari, Jami' al-Bayan 'an Ta'wil al-Qur'an (Beirut: Li alThaba'ah wa al-Nasyr wa al-Tauzi' wa al-I’lan, t.t), jilid 4, hlm. 199.

${ }_{41}$ M. Quraish Shihab, Tafsir al-Misbah..., jilid. 1, 503-504.

42 Fazlur Rahman, Islam dan Modernitas tentang Transformasi Intelektual, terj. Ahsin Mohammad (Bandung: Penerbit Pustaka, 1985), hlm. 6. 
pertumbuhan sebuah moral dari pesan Alqur'an. ${ }^{43}$ Oleh karena itu, konteks sosiohistoris wahyu merupakan elemen wahyu yang fundamental.

Secara sosio-historis, Alqur'an muncul dalam kebudayaan yang sangat diskriminatif terhadap perempuan. Ini merupakan realitas dari peradaban patriarki ketika itu, ${ }^{44}$ di samping kondisi masyarakatnya yang nomaden. Alqur'an bersikap realistik dalam komunitas yang seperti ini. Melalui teks-teks yang diturunkan, Alqur'an sejatinya sedang berusaha melakukan transformasi kultural secara arif dan realistik. Husein Muhammad menjelaskan bahwa pembacaan kritis struktur sosialbudaya bangsa Arab di saat Alqur'an turun, terutama yang menyangkut perempuan, menunjukkan dengan jelas betapa proses-proses transformasi sosial-budaya tengah dilakukan oleh Islam dengan sangat progresif. ${ }^{45}$ Umar ibn Khattab pernah berkata bahwa ketika Jahiliyah, orang-orang Arab sama sekali tidak pernah memandang penting kaum perempuan. Tetapi ketika Islam datang dan Tuhan menyebut mereka, orang-orang Arab baru menyadari bahwa kaum perempuan memiliki hak atas lakilaki. $^{46}$

Kebudayaan diskriminatif terhadap perempuan di masa pra-Islam, terutama dalam permasalahan reproduksi perempuan, di antaranya tercermin dalam perlakuan masyarakat pra-Islam terhadap perempuan menstruasi, yang selanjutnya menyebabkan QS. al-Baqarah (2): 222 turun. Masyarakat Arab ini memperlakukan perempuan yang sedang menstruasi dengan sangat tidak humanis. Mereka mempunyai peraturan terhadap wanita-wanita yang sedang menstruasi, bahwa wanita menstruasi harus mengasingkan diri dan segala yang disentuh atau didudukinya menjadi najis. ${ }^{47}$

Peraturan ini berdampak juga pada relasi suami-istri. Para suami tidak bersedia makan-minum bersama istri yang menstruasi, bahkan tidak tinggal serumah. Perlakukan yang seperti ini juga ditemukan dalam masyarakat Yahudi Madinah. Di antara perlakuan orang-orang Yahudi terhadap istrinya yang menstruasi adalah memberikan tempat bagi wanita yang sedang menstruasi terpisah selama tujuh hari, menyentuh mereka menjadikan ternoda dan najis, tidak diperbolehkan tinggal serumah, tidak boleh makan dan minum, serta tidak boleh tidur bersama. ${ }^{48} \mathrm{Hal}$ inilah

\footnotetext{
43 Toshihiko Izutsu, Relasi Tuhan dan Manusia..., hlm. 11.

44 Sistem kekeluargaan bangsa Arab sebelum Islam berlaku sistem patriarki. Akibatnya adalah keturunan anak laki-laki mendapatkan peluang dan derajat yang lebih tinggi atas perempuan dalam mendapatkan fasilitas keluarga. Pandangan tentang peran anak laki-laki sebagai hak penuh pemegang tanggung jawab dan penopang keselamatan keluarga, suku, dan kabilah tetap berlaku dalam lingkungan keluarga dan masyarakat. Sebaliknya, anak perempuan cenderung dipandang sebatas penambah beban keluarga, suku, dan kabilah. Kenyataan ini mengakibatkan kehidupan anak-anak perempuan tidak jelas dan menentu. Hari-harinya hanya dihabiskan untuk beraktivitas dalam urusan kandang domba dan unta. Mereka mendapatkan penyusuan dan sibesarkan di tempat kumuh dan bahkan hanya mendapatkan sehelai jubah yang terbuat dari kain wol yang kasar.Zaitunah Subhan, $A l$ Qur'an dan Perempuan..., hlm. 264.

45 Husein Muhammad, Islam Agama Ramah Perempuan..., hlm. 17.

46 Ibid., hlm. 259.

47 Imam Abu Hasan Ali bin Ahmad al-Wahidi, Asbab Nuzul al-Qur'an..., hlm.77.

$48 \quad$ Ibid., hlm. 76.
} 


\section{6 | Analisis Gender atas Ayat-Ayat Reproduksi Perempuan}

yang menjadi pertanyaan sahabat, yang membuat ayat tentang menstruasi turun. Sahabat Annas meriwayatkan bahwa Nabi juga merespon "segala sesuatu boleh kamu perbuat dengan istrimu yang sedang menstruasi selain bersetubuh" ${ }^{49}$

Selain tercermin dalam perlakuan masyarakat pra-Islam terhadap perempuan menstruasi, budaya diskriminatif pra-Islam juga ditemukan pada peran perempuan dalam permasalahan seks. Dalam hal seks, kaum perempuan di masa pra-Islam tidak memiliki hak atas tubuh mereka sendiri. Perempuan tidak memiliki hak untuk memutuskan kapan dan dengan siapa dia akan menikah. Kenikmatan seksual sebagai bagian dari hak reproduksi perempuan hanya menjadi milik kaum laki-laki. Bahkan, terdapat budaya Arab yang sengaja mereduksi kenikmatan seks perempuan dengan memotong clitoris atau juga bibir kecil vagina, yang biasa disebut dengan mutilasi genital. ${ }^{50}$

Singkatnya, kaum perempuan Arab pra-Islam dipaksa menjadi budak nafsu kaum laki-laki. Ketika Islam hadir, Alqur'an memberikan kepada kaum perempuan hak-hak yang sama dengan laki-laki. Nabi bahkan menyebut perempuan sebagai mitra laki-laki. Dalam relasi seksual, Islam juga memberikan perempuan hak penikmatan seksual sebagaimana yang dinikmati laki-laki. ${ }^{51}$

Beban dan resiko sistem reproduksi juga tidak kalah beratnya dirasakan oleh perempuan melahirkan di masa pra-Islam. Dalam sejarah, Islam lahir di tengah masyarakat Jahiliyah, suatu masa ketika seorang ibu melahirkan bayi wanita, maka bayi itu harus dikubur dalam keadaan hidup-hidup. Jika bayi perempuan dibiarkan hidup, maka sang-ibu akan menanggung cercaan, celaan, dan hidup dalam keadaan hina. ${ }^{52}$

Kecenderungan yang kuat untuk mempunyai anak dengan memilih jenis kelamin laki-laki banyak terjadi di masa pra-Islam. Ibnu Abbas menceritakan bahwa pada zaman Jahiliah terdapat orang yang segera menggali lubang di sekitar rumahnya ketika istrinya mulai merasa sakit dan akan melahirkan. Istrinya diminta melahirkan di muka lubang yang telah disediakan. Jika bayi yang terlahir perempuan, maka langsung masuk lubang dan segera ditimbun dengan tanah. ${ }^{53}$

Terkait tanggung jawab dan resiko sistem reproduksi ini, Nabi menegaskan agar laki-laki menjadi orang baik terhadap istri dan anak-anaknya. Dalam sebuah hadis yang diriwayatkan oleh Ibnu Majah, Nabi berkata kepada sahabat untuk saling berpesanlah di antara mereka agar selalu berbuat baik kepada perempuan, karena mereka sering kali tidak diperhitungkan oleh para laki-laki. Nabi menegaskan bahwa laki-laki tidak memiliki hak sama sekali atas perempuan, kecuali dengan berbuat baik.

\footnotetext{
49 Zaitunah Subhan, Al-Qur'an dan Perempuan..., hlm. 232.

Husein Muhammad, Islam Agama Ramah Perempuan..., hlm. 260.

Ibid., hlm. xxxiii.

Zaitunah Subhan, Al-Qur'an dan Perempuan..., hlm. 263.

Ibid., hlm. 264.
} 


\section{Analisis Gender atas Ayat-ayat Reproduksi Perempuan dalam Alqur'an}

Pandangan Alqur'an terhadap sistem reproduksi perempuan dalam bagian ini, akan didiskusikanmelalui perspektif teorigender. Gendersebagai teoriumumnya digunakan oleh penganut aliran konflik untuk memusatkan perhatiannya pada ketidakadilan struktur dan sistem yang disebabkan oleh gender, di samping mendeskripsikan pembedaan laki-laki dan perempuan dalam konstruksi masyarakat. ${ }^{54}$ Ketidakadilan gender dapat muncul di berbagai aspek kehidupan dalam bermasyarakat dan bernegara, bahkan beragama.

Sebagaimana yang telah disebutkan sebelumnya bahwa Alqur'an turun dalam kebudayaan yang sangat diskriminatif terhadap perempuan, yang merupakan relaitas dari peradaban patriarki yang dominan saat itu. Terdapat beberapa bentuk diskriminasi di masa pra-Islam yang bertolak dari sistem reproduksi perempuan. Pertama, adalah stereotipe atau pelabelan negatif terhadap perempuan, yang terlihat dalam kasus perempuan menstruasi dan hinanya ibu yang melahirkan bayi perempuan. Kedua, adalah subordinasi atau penomorduaan perempuan, yang dapat dilihat dalam kasus perempuan sebagai objek seksual di masa pra-Islam. Ketiga, adalah marginalisasi yang dapat dilihat dalam kasus tidak adanya peran perempuan dalam menentukan dengan siapa dirinya harus menikah dan berhubungan seks. Keempat, peran ganda yang dapat dilihat dalam kasus tanggungjawab seorang ibu ketika melahirkan bayi perempuan, sedangkan di sisi lain harus menanggung beban reproduksi. Kelima, kekerasan terhadap perempuan yang dialami perempuan pra-Islam, baik fisik maupun psikis karena proses reproduksi yang dialaminya. Dan yang terakhir, dari semua kasus tersebut menghasilkan bentuk diskriminasi gender yang berupa kekerasan terhadap perempuan Arab pra-Islam.

Secara realistik dan evolutif, Alqur'an berusaha melakukan transformasi terhadap kebiasaan dan tata cara hidup yang diskriminatif terhadap perempuan tersebut. Alqur'an telah membicarakan berbagai persoalan perempuan, termasuk di dalamnya persoalan-persoalan yang berkaitan dengan sistem reproduksi mereka. Berdasarkan struktur sosial bangsa Arab pada saat Alqur'an diturunkan, aturan yang menyangkut persoalan perempuan, termasuk permasalah sistem dan fungsi reproduksi perempuan, mengalami proses transformasi.

Stereotipe terhadap perempuan menstruasi adalah salah satu bentuk diskriminasi perempuan di masa pra-Islam. Tidak tanggung-tanggung, wanita yang menstruasi di masa ini dilabeli sebagai najis, sehingga mereka diberikan tempat terpisah selama menstruasi, dilarang makan dan tidur bersama. Ketika Islam datang, Alqur'an menjelaskan bahwa konsep haidl adalah sebuah gangguan bagi perempuan yang larangannya hanya dalam hal bersetubuh, bukan interaksi sosial. Selain itu, karena gangguan ini meliputi rasa sakit dalam hal fisik dan psikis wanita, menjahui secara sosial hanya akan menambah rasa sakit bagi perempuan.

$54 \quad$ Inayah Rohmaniyah, Gender dan Konstruksi Patriarki..., hlm. 15. 
Bentuk lain dari stereotipe di masa pra-Islam adalah hinanya ibu yang melahirkan bayi berjenis kelamin perempuan. Ketika ia melahirkan bayi perempuan dan dibiarkannya hidup, maka ia akan menanggung cercaan, celaan, dan hidup dalam keadaanhina. Namun, melaluicerita Maryam, Alqur'an menegaskan bahwa perempuan melahirkan mengalami sakit yang luar biasa, yang disebut dengan kontraksi. Ini menunjukkan akan bentuk empati Alqur'an kepada perempuan melahirkan. Selain itu, beban sosial yang dialami Maryam yang membuat Maryam mengasingkan diri untuk mendapatkan ketenangan, menunjukkan perlunya dukungan dari lingkungan sekitar terhadap perempuan melahirkan.

Selanjutnya, bentuk diskriminasi gender yang berakar dari sistem reproduksi adalah kedudukan perempuan di masa pra-Islam berada di bawah subordinasi lakilaki. Di antaranya adalah permasalahan seks sebagai salah satu fungsi reproduksi, baik bagi laki-laki maupun perempuan. Di masa pra-Islam, perempuan tidak memiliki hak atas tubuh mereka. Kenikmatan seksual sebagai bagian dari hak reproduksi perempuan hanya menjadi milik kaum laki-laki. Namun, setelah Islam hadir perempuan diberikan hak-hak yang sama dengan laki-laki dan menempatkan perempuan sebagai mitra lakilaki. Dalam relasi seksual, perempuan diberikan hak penikmatan seksual sebagaimana laki-laki (QS. al-Baqarah (2): 228 dan 187).

Begitupun dalam hal tanggung jawab seks sebagai sistem reproduksi, yang mana tanggung jawab seks sebagai sistem reproduksi tidak hanya menjadi beban istri, namun juga suami. Hal ini mengingat bahwa rahim istri adalah tempat terjadinya pembuahan dalam proses seks sebagai sistem reproduksi. Alqur'an mengibaratkan perempuan sebagai ladang, yang subur-tidaknya ladang sangat bergantung kepada petani. Dan suami itulah ibarat pemilik ladang atau petani. Dalam konteks suami-istri, hendaknya suami lebih memperhatikan istrinya. Suami harus menghindarkan istri dari berbagai gangguan, yang ibarat ladang adalah hama. Suami harus memberikan istri berbagai kebaikan untuk menyiapkan pertumbuhan dan perkembangan janin yang akan dikandungnya.

Tanggung jawab reproduksi perempuan yang harus melibatkan suami secara nyata juga dapat dilihat dalam permasalahan menyusui. Dalam hal ini, suami wajib memberikan nafkah ASI kepada anaknya sesuai dengan kemampuannya. Ini bisa dilakukan dengan memberikan fasilitas makanan bergizi dan papan yang layak kepada ibu yang menyusuinya, atau dengan menyusukan anaknya ke perempuan lain dengan memberikan upah. Dari sini perempuan tidak akan mengalami beban ganda atau berlebih, di samping beban reproduksi yang telah diembannya.

Selain merujuk kepada transformasi Alqur'an atas sistem sosial-budaya praIslam, realitas diskriminasi gender yang berkembang saat ini juga menunjukkan bahwa Alqur'an mampu memberikan solusi atas permasalahan gender, terutama terkait sistem reproduksi. Mengutip dari Husein Muhammad yang menyebutkan dalam bukunya bahwa berdasarkan laporan internasional setiap tahun lebih dari setengah 
juta perempuan meninggal karena sebab-sebab yang berkaitan dengan kehamilan dan melahirkan. Tujuh puluh ribu orang meninggal karena keguguran. Tujuh juta bayi meninggal di setiap tahunnya karena ibunya secara fisik belum siap melahirkan atau kurang mendapatkan perawatan yang memadahi. ${ }^{55}$

Alqur'an melalui ayat-ayatnya sadar akan rentannya sistem dan fungsi reproduksi perempuan ini. Dalam beberapa ayatnya, kerentanan ini dikatakan oleh Alqur'an dengan adza (gangguan), wahnan 'ala wahnin (lemah yang bertambah lemah), kurhan (kondisi yang tidak nyaman), dan mahadl (sakit karena kontraksi). Selain itu, pengistilahan perempuan sebagai harstun, mengharuskan suami untuk memperhatikan dan bertanggungjawab atas proses reproduksi perempuan sampai terjadinya kelahiran dan pertumbuhan anak. Ketika anak itu lahir, suami bertanggungjawab menafkahinya mulai dari penyusuan sampai pada pertumbuhannya.

Oleh karena itu, Alqur'an menegaskan akan pentingnya keterlibatan dan dukungan suami atau lingkungan kepada perempuan yang mengalami siklus reproduksi. Penegasan kepada laki-laki dan lingkungan ini dimaksudkan agar mereka memiliki empati dan memberikan dukungan yang memadahi terhadap perempuan yang secara kodrati berbeda dengan laki-laki karena mengalami siklus reproduksi. Jika tidak, maka siklus reproduksi ini sedikit banyak akan menghambat perempuan dari manfaat-manfaat tertentu di domestik maupun publik.

\section{PENUTUP}

Dari sini dapat disimpulkan bahwa; pertama, Alqur'an telah membicarakan berbagai persoalan perempuan, termasuk di dalamnya persoalan-persoalan yang berkaitan dengan sistem reproduksi mereka. Setidaknya terdapat lima siklus reproduksi perempuan yang dibicarakan oleh Alqur'an, yaitu berkenaan dengan menstruasi, pembuahan atau seks, kehamilan, melahirkan, dan menyusui. Dalam beberapa ayat yang menyinggung siklus reproduksi perempuan, nampaknya Alqur'an bersikap empati atas kerentanan yang dialami perempuan dalam siklus reproduksinya. Kerentanan ini dikatakan oleh Alqur'an dengan adza (gangguan), wahnan 'ala wahnin (lemah yang bertambah lemah), kurhan (kondisi yang tidak nyaman), mahadl (sakit karena kontraksi), dan harstun untuk terma yang mengharuskan perempuan mendapatkan perhatian.

Kedua, ketika merujuk kepada kebudayaan Arab pra-Islam maka sesungguhnya Alqur'an telah melakukan transformasi kultural terhadap sistem patriarki yang sangat diskriminatif terhadap perempuan. Beberapa bentuk diskriminasi di masa pra-Islam yang bertolak dari sistem reproduksi perempuan, dicoba dihapuskan oleh Alqur'an. Alqur'an memberikan kepada kaum perempuan hak-hak yang sama dengan laki-laki, termasuk dalam hal seksualitas. Alqur'an menegaskan agar laki-laki dan lingkungan

\footnotetext{
55 Husein Muhammad, Islam Agama Ramah Perempuan..., hlm. 258.
} 
40 | Analisis Gender atas Ayat-Ayat Reproduksi Perempuan

turut terlibat terkait tanggung jawab dan resiko sistem reproduksi yang dialami perempuan.

\section{REFERENSI}

Angga, La Ode. 2011. Hak Reproduksi Perempuan dalam Perspektif Syari'ah Islam. Muwazah, vol. 3, no. 2.

Asfahani, Abu al-Qasim al-Husein bin Muhammad ar-Raghib. 2005. al-Mufradat fi Gharib al-Qur'an, ed. Muhammad Khalil 'Itaniy. Beirut: Dar al Ma'rifah.

Baqiy, Muhammad Fu'ad Abdul. 1981. al-Mu'jam al-Mufahras li Alfāza al-Qur'ān alKarim. Beirut: Dar al-Fikr.

Dewi, Ratna. 2019. Konsep Kesehatan Reproduksi Perempuan dalam al-Qur'an. Mawa'izh: Jurnal Dakwah dan Pengembangan Sosial Kemanusiaan, vol. 10, no. 2.

Fakih, Mansour. 2012. Analisis Gender dan Transformasi Sosial. Yogyakarta: Pustaka Pelajar.

Hannah, Neng. 2017. Seksualitas dalam Alqur'an, Hadis, dan Fiqih: Mengimbangi Wacana Patriarki. Wawasan: Jurnal Ilmiah Agama Sosial Budaya, vol. 2, no. 1.

Izutsu, Toshihiko. 2003. Relasi Tuhan dan Manusia terj. Amiruddin dkk. Yogyakarta: PT. Tiara Wacana.

Khomisah M.A.. 2017. “Rekontruksi Sadar Gender: Mengurai Masalah Beban Ganda (Duble Bulder) Wanita Karier di Indonesia" dalam Jurnal al-Tsaqafa, vol. 14, no. 2.

Lubis, Namora Lumongga. 2013. Psikologi Kespro “Wanita dan Perkembangan Reproduksinya" Ditinjau dari Aspek Fisik dan Psikologinya. Jakarta: Kencana.s

Misrī, Jamāluddīn Muhammad ibn Mansūr. 2009. Lisān al- $\square$ Arāb. Beirut: Dār al-Kutub al-'Ilmiyyah.

Muhammad, Husein. 2004. Islam Agama Ramah Perempuan: Pembelaan Kiai Pesantren. Yogyakarta: LKiS.

Naan. 2021. Hak dan Kesehatan Reproduksi Perempuan dalam Islam. http:/ / digilib.uinsgd. ac.id. Diakses pada tanggal 15 April 2021.

Rahman,Fazlur. 1985. Islam dan Modernitas tentang Transformasi Intelektual, terj. Ahsin Mohammad. Bandung: Penerbit Pustaka. 
Analisis Gender atas Ayat-Ayat Reproduksi Perempuan | 41

Rofi'ah, Nur dan Ina Salma Febriany. 2019. Islam dan Upaya Peningkatan Kesehatan Reproduksi Perempuan: Tinjauan Kritis Ayat-ayat Reproduksi. al-Tadabbur: Jurnal Kajian Sosial, Peradaban dan Agama, vol. 5, no. 2, 2019.

Rohmaniyah, Inayah. 2020. Gender dan Konstruksi Patriarki dalam Tafsir Agama. Yogyakarta: Suka Press.

Setiawan, Iwan. 2017. Tafsir Ayat al-Qur'an Tema Keperawatan, Kebidanan, dan Fakta Ilmiahnya. Journal of Health Studies, vol. 1, no. 2.

Shihab, M. Quraish. 2006. Tafsir al-Misbah: Pesan, Kesan, dan Keserasian al-Qur'an. Jakarta: Lintera Hati.

Subhan, Zaitunah. 2015. Al-Qur'an dan Perempuan: Menuju Kesetaraan Gender dalam Penafsiran. Jakarta: Kencana. 1999. Tafsir Kebencian: Studi Bias Gender dalam al-Qur'an. Yogyakarta: LKiS.

Suharnanik dan Ulfah Muhayani. 2015. Bias Gender dalam Kamus Bahasa Indonesia on-line (Studi Kritis tentang Pemaknaan Perempuan dalam Kamus Bahasa Indonesia). Egalita: Jurnal Kesetaraan dan Keadilan Gender, Vol. 10, No. 2, 2015.

Tafsir as-Sa'di atas QS. Luqman (31): 14 dalam Program Ayat-ayat Situs al-Qur'an, King Saud University.

Thabari, Abu Ja'far Muhammad bin Jarir. Jami' al-Bayan 'an Ta'wil al-Qur'an. Beirut: Li al-Thaba' ah wa al-Nasyr wa al-Tauzi' wa al-I'lan, t.t.

Thanthawi, Muhammad Sayyid. 2013. At-Tafsir al-Wasith lil Qur'an al-Karim. Mesir: alHai'ah al-'Amah li Syu'un al-Mathabi' al-Amiriyyah.

Wahidi, Imam Abu Hasan Ali bin Ahmad. 1991. Asbab Nuzul al-Qur'an. Beirut: Dar alKutub al-'Alamiyah. 